\title{
Hepatitis viruses: Not always what it seems to be
}

\author{
JUAN FERNANDO GALLEGOS-OROZCO, JORGE RAKELA-BRÖDNER
}

Mayo Clinic Arizona Scottsdale, Arizona. USA. Correspondencia a: Dr. Jorge Rakela-Brödner E-mail: rakela.jorge@mayo.edu

\section{ABSTRACT}

The classic hepatotropic viruses, hepatitis $A$ through $E$, are not the only viral agents able to infect the liver. Other systemic viruses may cause hepatic injury that can range from mild and transient elevation of aminotransferases to acute hepatitis and occasionally acute liver failure and fulminant hepatitis. The clinical presentation may be indistinguishable from that associated with classic hepatotropic viruses. These agents include cytomegalovirus; Epstein-Barr virus; herpes simplex virus; varicellazoster virus; human herpesvirus 6, 7, and 8; human parvovirus B19; adenoviruses among others. Wide spectrums of clinical syndromes are associated with cytomegalovirus disease. Unique clinical syndromes may present in neonates, young adults and immunocompromised hosts infected with cytomegalovirus. Cases of fulminant hepatitis have been reported in both immunocompromised and immunocompetent hosts infected with Epstein Barr virus. Occasionally, these patients with acute hepatic failure may need liver transplantation. Herpes simplex viruses may involve the liver in neonatal infections, pregnancy, immunocompromised hosts and occasionally, immunocompetent adults. Varicella-Zoster virus has also been associated with severe acute hepatitis and fulminant hepatitis in adults. The drug of choice for these conditions is intravenous acyclovir. These may also need liver transplantation in the more severe forms of clinical presentation. Typical liver biopsy findings can be useful in determining the diagnosis of these viral infections. Human herpesviruses 6, 7, and 8 , human parvovirus B19, and adenoviruses can also be present with features of acute liver injury and occasionally as fulminant hepatitis. The clinical syndromes are less well delineated than those associated with herpesviruses. It is important to consider these viruses as possible etiologic agents in patients who have acute liver injury and their serologic markers for the classic hepatotropic viruses are not indicative of an active infection.

(Rev Med Chile 2010; 138: 1302-1311).

Key words: Cytomegalovirus; Hepatitis, viral, human; Hepatitis viruses; Herpesviridae.

\section{Los virus de las hepatitis no siempre son los habituales}

Los agentes de la hepatitis viral $A, B, C, D$ y E no son los únicos virus que pueden causar un síndrome de daño hepático agudo. Agentes virales como el citomegalovirus, Epstein-Barr, herpes simplex 1 y 2, varicella-zoster, virus herpes humano 6, 7, y 8, parvovirus B19 y adenovirus pueden causar daño hepático agudo e inclusive presentarse como hepatitis fulminante. Los cuadros clinicos de daño hepático agudo por citomegalovirus, Epstein Barr y herpes simplex 1 y 2 han sido caracterizado mejor. Se 
ha intentado el uso de drogas antivirales específicas como el uso intravenoso de aciclovir. Ocasionalmente, se ha requerido el trasplante hepático para rescatar pacientes con hepatitis fulminantes por estos agentes virales. La biopsia hepática puede ser de utilidad en estos casos puesto que los hallazgos son bastante característicos. La expresión clínica asociada a infecciones por virus herpes humano 6, 7 y 8, parvovirus B19y adenovirus son menos características. Ha habido varios casos de hepatitis fulminante causada por estos agentes virales. Estos agentes virales deben ser considerados en el diagnóstico de casos de daño hepático agudo e inclusive hepatitis fulminante cuando los marcadores virales para los virus de hepatitis A-E son negativos.

T he classic hepatotropic viruses, hepatitis A through E, are not the only viral agents capable of infecting the liver. Other viruses may affect the liver as part of organ-specific or systemic involvement, with hepatic injury that can range from mild and transient elevations in aminotransferases to acute hepatitis and occasionally acute liver failure and fulminant hepatitis (FHF). Their ability to cause chronic liver disease has not been proven unequivocally. These agents include cytomegalovirus; Epstein-Barr virus; herpes simplex virus; varicella-zoster virus; human herpesvirus 6, 7, and 8; human parvovirus B19; adenoviruses; among others.

\section{Cytomegalovirus}

Human cytomegalovirus $(\mathrm{CMV})^{1}$ is the largest member of the betaherpesviridae family. The cellular response to CMV infection is characterized by cytomegaly and prominent intranuclear inclusion bodies (Figure 1). CMV infections are common, affecting $60 \%-70 \%$ of adults, and play a significant role as an opportunistic pathogen in immunocompromised hosts. Early recognition of infection, institution of therapy, and prevention of infection are critical in altering the outcome in these patients ${ }^{2}$.

Several factors determine the manifestations and severity of CMV infection. Infection is acquired either in the perinatal period and infancy or in adulthood through sexual contact, blood transfusions, or organ transplantation. Most primary CMV infections in immunocompetent adults are asymptomatic or associated with a mild mononucleosis-like syndrome. As with other herpes viruses, all primary infections resolve and enter into lifelong latency in which live virus is sequestered in a nonreplicative state. Persons with latent infection and intact immune system have no symptoms but exhibit antibodies to CMV. Circulating lymphocytes, monocytes, and polymorphonuclear leukocytes may serve as the predominant site of viral latency. The risk for intermittent reactivation is increased with immunosuppression. In immunocompromised patients, CMV disease can result from either a primary infection, or more commonly, from reactivation of latent infection. Although adequate anti-CMV antibodies are detected during episodes of infection reactivation, cell-mediated immunity, characterized by decreased numbers of cytotoxic T lymphocytes and natural killer cells, is defective. The incidence and severity of CMV disease closely parallels the degree of cellular immune dysfunction ${ }^{3}$.

A wide spectrum of clinical syndromes are associated with CMV disease ranging from asymptomatic infection to life-threatening congenital CMV syndrome in neonates, infectious mononucleosis syndrome in young adults, to severe pulmonary, retinal, neurological, gastrointestinal, and hepatic diseases in immunocompromised hosts, in whom $\mathrm{CMV}$ is a very common opportunistic pathogen.

In immunocompetent children and adults, CMV infection is usually subclinical but sometimes can cause a disease that resembles EpsteinBarr virus (EBV) infectious mononucleosis syndrome ${ }^{4}$.

Liver dysfunction is commonly associated with CMV mononucleosis. It is usually mild and rarely symptomatic in the immunocompetent patient. Hepatosplenomegaly and laboratory evidence of mild to moderate hepatic dysfunction are the predominant features, with increased aminotransferases and alkaline phosphatase in $88 \%$ and $64 \%$ of cases, respectively, but lower than commonly 


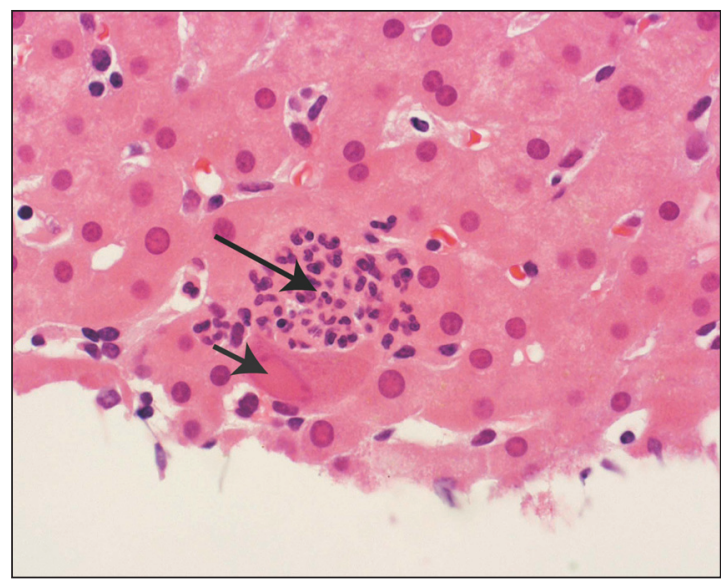

Figure 1. CMV hepatitis. the long arrow shows a microabscess and the short arrow a CMV nuclear inclusion. Magnification 100x; hematoxylin and eosin stain.

encountered in active viral hepatitis ${ }^{5}$. Rare manifestations of CMV hepatitis include tender hepatomegaly, granulomatous hepatitis, anicteric or icteric cholestatic hepatitis, and acute hepatitis with massive necrosis.

In patients with impaired cell-mediated immunity, disseminated CMV infection results in serious life threatening diseases. CMV is the most common opportunistic viral infection in AIDS patients causing retinitis, central nervous system infections, esophagitis, and colitis. CMV may also invade the hepatobiliary tract in AIDS patients causing hepatitis, pancreatitis, and acute acalculous cholecystitis ${ }^{6,7}$. The presence of cytomegalovirus retinitis, gastrointestinal disease, or viremia in AIDS patients increases the risk for the development of a cholestatic syndrome caused by papillary stenosis and sclerosing cholangitis (AIDS cholangiopathy), which does not usually respond to antiviral therapy ${ }^{8}$. Other immunocompromised patients at risk are organ transplant recipients.

The diagnosis of CMV hepatitis requires confirmatory laboratory tests. Serologic studies of CMV-IgM antibodies may be helpful in primary infections in immunocompetent hosts. Viral culture techniques could be greatly enhanced with the use of "shell vial" assays, using CMV early antigens ${ }^{9}$. Using molecular techniques to detect CMV early antigen or the CMV DNA, increases the sensitivity of detecting CMV infection in blood or tissue ${ }^{10}$.

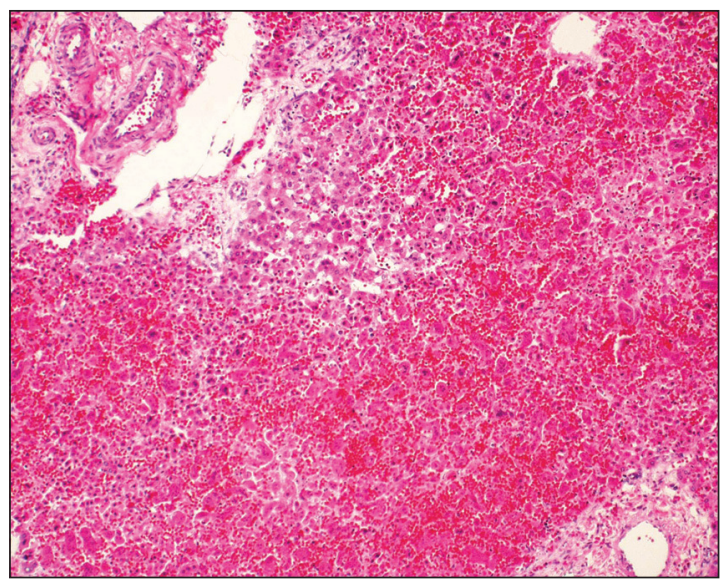

Figure 2. Massive hepatic necrosis due to HSV-1. Magnification 20x; hematoxylin and eosin stain.

To clearly establish the diagnosis of active CMV infection, it is necessary to have histological evidence of cellular injury associated with infection. Distinct pathologic findings on liver biopsy are important in establishing the diagnosis of CMV hepatitis, especially in the immunocompromised host. Giant multinucleated cell reaction with an inflammatory response, multifocal necrosis, and biliary stasis are commonly found. Large nuclear inclusion-bearing cells, so-called "owl's eye" inclusions, can be found in hepatocytes or bile duct epithelium ${ }^{11}$.

Hepatitis is the most frequent organ-specific complication from CMV infection after liver transplantation, affecting approximately $10 \%$ of recipients; with a higher incidence among seronegative recipients compared to seropositive patients, $26 \%$ vs $9 \%$. In these cases, infection generally occurs as a consequence of reactivation rather than primary infection.

Treatment of CMV with antiviral agents is not always indicated, especially in self-limited disease in immunocompetent adults. For severe cases, particularly in patients with impaired cell-mediated immunity, therapy can be life saving. Drugs approved for treatment of CMV disease include ganciclovir, valganciclovir, foscarnet and cidofovir. Ganciclovir is considered the antiviral agent of choice against CMV. The duration of therapy should be guided by repeated measurements of $\mathrm{CMV}$ in blood samples. Emerging strains resistant 
to ganciclovir pose a therapeutic challenge, where foscarnet or cidofovir may become alternative antiviral agents ${ }^{12}$. A more recent addition is valganciclovir, which has been evaluated among liver transplant recipients with CMV disease ${ }^{13}$.

\section{Epstein-Barr Virus}

Epstein-Barr Virus (EBV) shares the characteristic morphologic features of the Herpesviridae family. Its genome consists of a linear DNA molecule that encodes nearly 100 viral proteins. After infecting B-lymphocytes, the linear EBV genome becomes circular, forming an episome, which usually remains latent in these B cells. Viral replication is spontaneously activated in only a small percentage of latently infected B cells ${ }^{14}$. EBV infection is a very common and life-long infection affecting over $90 \%$ of humans worldwide.

Transmission of EBV usually occurs by contact with oral secretions. Although rare, transmission through blood transfusion has been reported. EBV replicates in nasopharyngeal epithelial cells, and seropositive persons actively shed virus in saliva. $\mathrm{B}$ cells in the oropharynx may be the primary site of infection. Resting memory B cells are thought to be the site of persistence of EBV within the body. Various clinical conditions have been associated with EBV, such as infectious mononucleosis, Burkitt's lymphoma, nasopharyngeal carcinoma, Hodgkin's disease, peripheral T-cell lymphoma, and post-transplant lymphoproliferative disease ${ }^{15}$.

Liver involvement is well recognized in EBV infection. Manifestations of liver involvement range from the mild self-limiting acute hepatitis to occasional reports of fatal acute fulminant hepatitis ${ }^{16}$.

Mild elevation of aminotransferases and elevated lactic dehydrogenase are seen in up to $90 \%$ of cases of infectious mononucleosis. Typically, the rise in aminotransferases is gradual, reaching a peak that is lower than that commonly encountered in acute viral hepatitis. Patients older than 30 years generally have a more severe disease than children. Mild elevation of alkaline phosphatase is also seen in $60 \%$ and mild hyperbilirubinemia in about $45 \%$.

Severe cholestatic jaundice and right upper quadrant abdominal pain may occur in elderly patients. Jaundice may occasionally be the initial clinical presentation, in combination with fever and abdominal pain, and can be mistaken for extrahepatic biliary obstruction. Jaundice predominantly occurs when EBV infection is complicated with autoimmune hemolytic anemia, and occasionally as a direct result of virus-induced cholestasis $^{17,18}$.

Other occasional clinical settings for EBV liver involvement include post-transfusion hepatitis, granulomatous hepatitis, and fatal fulminant hepatitis. In some cases of granulomatous hepatitis, serologic evidence of chronic EBV infection was found ${ }^{19,20}$. Cases of fatal fulminant hepatitis with massive hepatic necrosis and disseminated intravascular coagulation have been reported in both immunocompromised and immunocompetent hosts $^{21-23}$.

Diagnosis of infectious mononucleosis is established on the basis of clinical features, laboratory and serological findings indicative of a recent EBV infection. The most common hematological findings include leukocytosis in $70 \%$ of cases, with predominantly lymphocytosis and monocytosis, and mild thrombocytopenia in up to $50 \%$. The "monospot" test that detects heterophil antibodies, while sensitive, is not very specific. EBV-specific IgG and IgM antibodies, directed against the viral capsid antigens-VCA, early antigens -EBV anti-D and anti-R, nuclear antigen-EBVNA, and soluble complement-fixing antigens -anti-S, improve sensitivity and specificity in detecting the infection ${ }^{24}$. In the vast majority of cases there is no indication for liver biopsy, but when performed there may be portal and sinusoidal mononuclear cell infiltration with focal hepatic necrosis or fatty infiltration. Of particular utility as diagnostic methods are in situ hybridization, Southern blot analysis, and polymerase chain reaction to identify specific RNA or DNA sequences in the involved organs ${ }^{25}$.

There are no specific diagnostic criteria for EBV hepatitis, but it is generally agreed that the following need to be present to establish the diagnosis: elevated aminotransferases, active EBV infection as defined by serology, typical pathologic changes on biopsy and demonstration of the viral genome in liver tissue by molecular methods.

There is no specific drug or treatment for EBV infection. Acyclovir inhibits EBV in vitro replication and reduces viral shedding in the oropharynx but has no effect on the symptoms of infectious 
mononucleosis which are primarily due to the immune response against the virus and therefore not recommended ${ }^{26}$. Ganciclovir has been shown to be effective in the treatment of EBV hepatitis in a small number of children ${ }^{27}$. There is a single report of fulminant hepatic failure in an immunocompetent young girl caused by EBV infection that was treated by liver transplantation ${ }^{28}$.

\section{Herpes Simplex Virus}

Herpes simplex viruses, HSV-1 and HSV-2, commonly infect humans and produce a wide variety of illnesses. The clinical manifestations and course of HSV infections depend mainly on the site involved and the patient's age and immune status.

Occasionally, HSV viremia results in visceral involvement, affecting mainly three organs: esophagus, lungs, and liver. Liver involvement occurs in the following settings: neonatal infections, pregnancy, immunocompromised hosts, and rarely, immunocompetent adults.

In neonates, hepatitis occurs with multi-organ involvement and usually carries a high mortality rate $^{29,30}$. Delay in antiviral therapy, while awaiting confirmation of diagnosis, can lead to very poor outcomes $^{31}$.

HSV hepatitis in pregnant women was first reported in 1969 and was seen in the context of disseminated primary infection, generally during the third trimester and presenting as fulminant hepatitis $^{32,33}$. Mucocutaneous lesions are present in only half of cases; therefore, the clinical suspicion for diagnosis of this condition must be high. Twenty-five percent of cases were not diagnosed until autopsy. Early recognition with initiation of antiviral therapy may reverse an otherwise fatal process $^{34,35}$.

HSV is an uncommon cause of hepatitis in immunocompetent patients. A mild asymptomatic elevation of aminotransferases levels can be detected in $14 \%$ of healthy adults with acute genital infection ${ }^{36}$. Fulminant hepatitis with more than 100-fold rise in aminotransferases was reported and associated with a favorable outcome after antiviral therapy ${ }^{37}$. In immunocompromised hosts, HSV hepatitis has occurred during primary and, rarely, during recurrent infection, with a triad of fever, leukopenia and markedly elevated liver enzymes.
Liver biopsy is essential to establish the diagnosis of HSV hepatitis, especially in pregnancy. It usually shows focal, sometimes extensive, hemorrhagic or coagulative necrosis of the hepatocytes with limited inflammatory response (Figure 2). Typical intranuclear inclusions (Cowdry type A) are often identified at the margins of the foci of necrosis. The diagnosis is confirmed by detection of HSV DNA sequences by molecular techniques, which are more sensitive than tissue culture methods ${ }^{34,38,39}$.

HSV hepatitis is an infectious disease emergency associated with a rapid and lethal course, and requires early recognition and institution of antiviral therapy, while awaiting confirmation of diagnosis, in order to improve outcome ${ }^{40,41}$. At Mayo Clinic, the incidence of HSV hepatitis was reported to be $6 \%$ among all fulminant hepatitis cases from 1974 to $1982^{42}$. High dose acyclovir (at least $10 \mathrm{mg} / \mathrm{kg} /$ day every 8 hours) is the antiviral drug of choice $e^{34,43-45}$. Newer drugs with improved oral bioavailability include valacyclovir and famciclovir, but they are not generally indicated in severe forms of HSV infection. Shanley ${ }^{46}$ reported a case of a healthy female who developed disseminated HSV-2 infection and fulminant hepatitis during the third trimester of pregnancy requiring high dose antiviral therapy, which resulted in eradication of HSV mucocutaneous lesions. However, the patient's condition continued to deteriorate leading to liver transplantation. Recurrence was not observed, suggesting that disseminated HSV infection should not be an absolute contraindication for transplantation in certain clinical settings. Several series have also demonstrated the utility of liver transplantation in this setting ${ }^{47,48}$.

\section{Varicella-Zoster virus}

Varicella-Zoster virus (VZV) causes two distinct clinical diseases. Varicella is the primary infection, which is characterized by a benign generalized exanthematous rash. Recurrence of infection results in a localized phenomenon known as herpes zoster. Rare, non-cutaneous manifestations, such as encephalitis, pneumonitis, myocarditis, and hepatitis, may accompany the skin rash, especially in immunocompromised patients ${ }^{49}$.

Mild and transient liver enzyme abnormalities can occur in up to $25 \%$ of children with varicella ${ }^{50}$. 
Primary infection in immunocompetent adults may cause severe acute hepatitis with more than tenfold increase in aminotransferases ${ }^{51}$ and, sometimes, fulminant hepatic failure with evidence of VZV in liver and other organs ${ }^{52}$.

In contrast to the rather benign course of zoster (reactivation of infection) in the setting of organ transplantation, primary varicella infection can be quite aggressive ${ }^{53}$. Visceral involvement, including the liver, may occur in the immediate postoperative period or up to several months after transplantation. It is usually associated with rapid onset and fatal fulminant hepatitis ${ }^{54-56}$.

Serologic testing is of little value, especially in immunocompromised patients. Confirmation of diagnosis is possible through the isolation of VZV from skin lesions or from the affected organs. Liver biopsy often shows foci of coagulative necrosis and intranuclear inclusions with an inflammatory response. PCR and immunoperoxidase techniques are helpful to distinguish VZV from HSV hepatitis.

Centers for Disease Control (CDC, Atlanta, GA, USA) guidelines for the prevention and control of nosocomial infections are useful for infection control in hospital personnel ${ }^{57}$. Early administration of antiviral therapy is critical in the setting of VZV hepatitis, especially in immunocompromised patients. The drug of choice is intravenous acyclovir at a dose of $10 \mathrm{mg} / \mathrm{kg}$ every 8 hours for 7 to 10 days $^{58,59}$.

\section{Human Herpesvirus 6}

Nearly all infants by the age of 2 are infected by human herpesvirus 6 (HHV-6) which usually results in exanthema subitum also known as Roseola Infantum or Sixth Disease ${ }^{60}$. Attempts to prove an etiologic association of HHV-6 with liver injury have been inconclusive ${ }^{61}$. PCR techniques and in situ-hybridization led to isolation of HHV-6 from the liver tissue of infants with chronic hepatitis, suggesting HHV-6 as a causative agent ${ }^{62,63}$. Reactivation of infection may occur after solid organ transplantation with questionable clinical significance ${ }^{64}$.

A recent study reported ${ }^{65}$ the involvement of HHV-6 in 15 patients with non-A and non-E hepatitis who underwent liver transplantation for acute liver failure. HHV-6-specific antigens were analyzed in the explanted livers by immunohisto- chemistry, and the possible presence of the virus in peripheral blood mononuclear cells was demonstrated by HHV-6 antigenemia test. Of the 15 patients with acute liver failure of unknown cause, 12 demonstrated HHV-6 antigens in the liver. Most of these patients also demonstrated HHV-6 antigenemia. No other viruses were identified in liver tissue from these patients, leading the authors to speculate that HHV-6 may be a cause of acute liver failure. Although other investigators have detected HHV-6 in patients with acute hepatitis and fatal FHF ${ }^{65,66}$, these reports do not necessarily establish causality. This virus may be associated with hepatitis in liver transplant recipients; and the therapy of choice is ganciclovir or foscarnet ${ }^{67}$. Foscarnet has a better in vitro virus sensitivity than acyclovir and ganciclovir against HHV- $6^{68}$.

\section{Human Herpesvirus 7 and 8 (HHV-7 and HHV-8)}

HHV-7 also infects all humans by the age of 5 years causing febrile syndromes. Hepatitis in association with HHV-7 has been infrequently reported $^{69}$.

HHV-8, also called Kaposi's sarcoma-associated human herpesvirus 8 , has been detected consistently in Kaposi's sarcoma, lymphoma, multicentric Castleman's disease, in HIV- positive patients and occasionally in HIV- negative patients. Liver involvement may occur in Kaposi's sarcoma and other HHV-8 related malignancies in immunosuppressed patients, particularly in the setting of primary acute disseminated infection, such as seen in transplant recipients from an infected donor allograft or, less commonly, during $\mathrm{HHV}-8$ reactivation in HIV-infected individuals.

\section{Human Parvovirus B19}

Human parvovirus B19 (HPV B19) is a small DNA virus from the parvoviridae family ${ }^{70}$.

Human parvovirus B19 infection produces a spectrum of clinical manifestations including: erythema infectiosum or "fifth disease," in children; hydrops fetalis and fetal death; an arthritis syndrome associated with acute infections in adults; hematological disorders such as leukopenia, thrombocytopenia, transient aplastic crisis in patients with chronic hemolytic anemia, and 
chronic anemia in immunocompromised patients; other rare organ involvement include neurologic, cardiac, hepatic disease, and vasculitis.

Hepatic manifestations range from a transient elevation of serum aminotransferases ${ }^{71,72}$ sometimes seen during the course of erythema infectio$\operatorname{sum}^{73,74}$ to FHF ${ }^{75}$. HPV-B19 DNA has been found in liver samples from $67 \%$ of patients with non-A and non-E FHF and aplastic anemia, in 50\% of patients with cryptogenic FHF without aplastic anemia, compared to $15 \%$ of control subjects with chronic liver failure. This led some investigators to suggest that HPV-B19 is a possible causative agent of $\mathrm{FHF}^{76,77}$.

In most cases, HPV-B19 infection is a benign and self-limited infection and requires no treatment other than symptomatic relief $^{78}$. At Mayo Clinic, we reported two cases of a less severe form of hepatitis-associated aplastic anemia ${ }^{79}$.

\section{Adenoviruses}

There are close to 50 serotypes of adenoviruses causing acute infections of the respiratory system, conjunctivae, and gastrointestinal tract, and occasionally hemorrhagic cystitis, infantile diarrhea, intussusception, and central nervous system infections. Disseminated disease with multi-organ involvement has been reported in immunocompromised, and occasionally immunocompetent, patients and associated with an increased mortality ${ }^{80,81}$.

The role of adenovirus as an etiologic agent of hepatic damage has been controversial. Fatal cases of adenovirus infection with FHF were reported in immunosuppressed adults. Postmortem liver pathology revealed widespread hepatic necrosis with intranuclear inclusions within viable hepatocytes. Electron microscopy may show crystalline arrays of virions within hepatocytes ${ }^{82}$. Although no specific therapy for adenovirus hepatitis is currently available; cidofovir has been recently suggested to play a role in the treatment of adenovirus infection ${ }^{83}$.

\section{References}

1. Bonkowsky H, Lee R, Klatskin G. Acute granulomatous hepatitis. Occurrence in cytomegalovirus mononucleosis. JAMA 1975; 233: 1284-8.
2. Kim W, Badley A, Wiesner R, Porayko MK, Seaberg EC, Keating MR, et al. The economic impact of cytomegalovirus infection after liver transplantation. Transplantation 2000; 69: 357-61.

3. Goodgame R. Gastrointestinal Cytomegalovirus Disease. Ann Intern Med 1993; 119: 924-35.

4. Watanabe S, Arima K, Nishioka M, Yoshino S, Hasui H, Fujikawa M. Comparison between sporadic cytomegalovirus hepatitis and Epstein-Barr virus hepatitis in previously healthy adults. Liver 1997; 17: 63-9.

5. Kunno A, Abe M, Yamada M, Murakami K. Clinical and histological features of cytomegalovirus hepatitis in previously healthy adults. Liver 1997; 17: 129-32.

6. Roulot D, Valla D, Brun-Vezinet F, Rey MA, Clavel F, Degott $\mathrm{C}$, et al. Cholangitis in the acquired immunodeficiency syndrome: report of two cases and review of the literature. Gut 1987; 28: 1653-60.

7. Blumberg R, Kelsey P, Perrone T, Dickersin R, Laquaglia M, Ferruci J. Cytomegalovirus- and Cryptosporidiumassociated acalculous gangrenous cholecystitis. Am J Med 1984; 76: 1118-23.

8. Jacobson M, Cello J, Sande M. Cholestasis and disseminated cytomegalovirus disease in patients with the acquired immunodeficiency syndrome. Am J Med 1988; 84: 218-24.

9. Martin WI, Smith T. Rapid detection of cytomegalovirus in bronchoalveolar lavage specimens by a monoclonal antibody method. J Clin Microbiol. 1986;23:1006-1008.

10. Persing DH, Rakela J. Polymerase chain reaction for the detection of hepatitis viruses: panacea or purgatory? [editorial; comment]. Gastroenterology 1992; 103: 10989.

11. Espy M, Paya C, Holley K, Ludwig J, Hermans PF, Wiesner RH, et al. Diagnosis of cytomegalovirus hepatitis by histopathology and in situ hybridization in liver transplantation. Diag Microbiol Infect Dis. 1991.

12. Balfour HJ. Antiviral drugs. N Engl J Med 1999; 340: 1255-68.

13. Razonable RR. Cytomegalovirus infection after liver transplantation: current concepts and challenges. W J Gastroenterol 2008; 14: 4849-60.

14. Sixbey J, Nedrud J, Raab-Traub N, Hanes R, Pagano J. Replication of Epstein-Barr virus in human epithelial cells infected in vitro. Nature 1983; 306: 480-3.

15. Cohen J. Epstein-Barr virus Infections. N Engl J Med 2000; 343: 481-92.

16. Crum NF. Epstein Barr virus hepatitis: case series and review. Southern Med J 2006; 99: 544-7.

17. Edoute Y, Baruch Y, Lachter J, Furman E, Bassan L, Assy N. Severe cholestatic jaundice induced by Epstein-Barr virus infection in the elderly. J Gastroenterol Hepatol 
1998; 13: 821-4.

18. Hinedi TB, Koff RS. Cholestatic hepatitis induced by Epstein-Barr virus infection in an adult. Diges Dis Sci 2003; 48: 539-41.

19. Harrington P, Gutiérrez J, Ramírez-Ronda C, QuinonesSoto R, Bermúdez R, Chaffey J. Granulomatous hepatitis. Rev Infect Dis 1982; 4: 638-55.

20. Markin R, Linder J, Zuerlein K, et al. Hepatitis in fatal infectious mononucleosis. Gastroenterology 1987; 93: 1210-7.

21. Papatheodoridis GV, Delladetsima JK, Kavallierou L, Kapranos N, Tassopoulos NC. Fulminant hepatitis due to Epstein-Barr virus infection. J Hepatol 1995; 23: 34850 .

22. Davies M, Morgan-Capner P, Portmann B, Wilkinson S, Williams R. A fatal case of Epstein-Barr virus infection with jaundice and renal failure. Postgrad Med J 1980; 56: 794-795.

23. Halmos B, Anastopoulos H, Schnipper L, Ballesteros E. Extreme lymphoplasmacytosis and hepatic failure associated with sulfasalazine hypersensitivity reaction and a concurrent EBV infection-case report and review of the literature. Ann Hematol 2004; 83: 242-6.

24. Lloyd-Still JD, Scott JP, Crussi F. The spectrum of Epstein-Barr virus hepatitis in children. Pediatric Pathol 1986; 5(3-4): 337-51.

25. Markin R. Manifestations of Epstein-Barr virus-associated disorders in liver. Liver 1994; 14: 1-13.

26. van der Horst C, Joncas J, Ahronheim G, Gustafson N, Stein G, Gurwith M, et al. Lack of effect of peroral acyclovir for the treatment of acute infectious mononucleosis. J Infect Dis 1991; 164: 788-92.

27. Adams LA, Deboer B, Jeffrey G, Marley R, Garas G. Ganciclovir and the treatment of Epstein-Barr virus hepatitis. J Gastroenterol Hepatol 2006; 21: 1758-60.

28. Feranchak AP, Tyson RW, Narkewicz MR, Karrer FM, Sokol RJ. Fulminant Epstein-Barr viral hepatitis: orthotopic liver transplantation and review of the literature. Liver Transplant Surg 1998; 4: 469-76.

29. Hass G. Hepato-adrenal necrosis with intranuclear inclusion bodies. Am J Pathol 1935; 11: 127-42.

30. Hanshaw J. Herpesvirus hominis infections in the fetus and the newborn. Am J Dis Children 1973; 126: 456-555.

31. Benador N, Mannhardt W, Schranz D, Braegger C, Fanconi S, Hassam S, et al. Three cases of neonatal herpes simplex virus infection presenting as fulminant hepatitis. Eur J Pediat 1990; 149: 555-9.

32. Mudido P, Marshall GS, Howell RS, Schmid DS, Steger S, Adams G. Disseminated herpes simplex virus infection during pregnancy. A case report. J Reproduct Med 1993; 38: 964-8.
33. Fink CG, Read SJ, Hopkin J, Peto T, Gould S, Kurtz JB. Acute herpes hepatitis in pregnancy [see comments]. J Clin Pathol 1993; 46: 968-71.

34. Klein NA, Mabie WC, Shaver DC, Latham PS, Adamec TA, Pinstein ML, Riely CA. Herpes simplex virus hepatitis in pregnancy. Two patients successfully treated with acyclovir. Gastroenterology 1991;100: 239-44.

35. Kang AH, Graves CR. Herpes simplex hepatitis in pregnancy: a case report and review of the literature. Obst Gynecol Survey 1999; 54: 463-8.

36. Minuk G, Nicolle L. Genital herpes and hepatitis in healthy young adults. J Med Virol 1986; 19: 269-75.

37. Velasco M, Llamas E, Guijarro-Rojas M, Ruiz-Yague M. Fulminant herpes hepatitis in a healthy adult: a treatable disorder? J Clin Gastroenterol 1999; 28: 386-9.

38. Pellise M, Miquel R. Liver failure due to herpes simplex virus. J Hepatol 2000; 32: 170.

39. Chase RA, Pottage JC, Jr., Haber MH, Kistler G, Jensen D, Levin S. Herpes simplex viral hepatitis in adults: two case reports and review of the literature. Rev Infect Dis 1987; 9: 329-33.

40. Hofer S, Hunziker S, L T, Ludwig C. Fatal herpes simplex virus hepatitis complicating chemotherapy with weekly docetaxel. Ann Oncol 2003; 14: 340.

41. Peters D, Greene W, Ruggiero F, McGarrity T. Herpes simplex-induced fulminant hepatitis in adults: a call for empiric therapy. Digest Dis Sci 2000; 45: 2399-404.

42. Rakela J, Lange SM, Ludwig J, Baldus WP. Fulminant hepatitis: Mayo Clinic experience with 34 cases. Mayo Clin Proc 1985; 60: 289-92.

43. Gabel H, Flamholc L, Ahlfors K. Herpes simplex virus hepatitis in a renal transplant recipient: successful treatment with acyclovir. Scand J Infect Dis 1988; 20: 435-8.

44. Glorioso DV, Molloy PJ, Van Thiel DH, Kania RJ. Successful empiric treatment of HSV hepatitis in pregnancy. Case report and review of the literature. Digest Dis Sci 1996; 41: 1273-5.

45. Kaufman B, Gandhi SA, Louie E, Rizzi R, Illei P. Herpes simplex virus hepatitis: case report and review [see comments]. Clin Infect Dis 1997; 24: 334-8.

46. Shanley CJ, Braun DK, Brown K, Turcotte JG, Greenson JK, Beals TF, et al. Fulminant hepatic failure secondary to herpes simplex virus hepatitis. Successful outcome after orthotopic liver transplantation. Transplantation. 1995; 59: 145-9.

47. Pinna A, Rakela J, Demetris AJ, Fung JJ. Five cases of fulminant hepatitis due to herpes simplex virus in adults. Digest Dis Sci 2002; 47: 750-4.

48. Norvell JP, Blei AT, Jovanovic BD, Levitsky J. Herpes simplex virus hepatitis: an analysis of the published 
literature and institutional cases. Liver Transplantation 2007; 13: 1428-34.

49. Phuah HK, Chong CY, Lim KW, Cheng HK. Complicated varicella zoster infection in 8 paediatric patients and review of literature. Singapore Med J 1998; 39: 115-20.

50. Plotkin SA. Clinical and pathogenetic aspects of varicella-zoster. Postgrad Med J 1985; 61(Suppl 4): 7-14.

51. Fowler K, Stagno S, Pass R, Britt W, Boll T, Alford C. The outcome of congenital cytomegalovirus infection in relation to maternal antibody status. N Engl J Med 1992; 326: 663-7.

52. Anderson D, Schwartz J, Hunter N, Cottrill C, Bisaccia E, Klainer A. Varicella hepatitis: a fatal case in a previously healthy, immunocompetent adult. Report of a case, autopsy, and review of the literature. Arch Intern Med 1993; 154: 2101-6.

53. Rubin R, Tolkoff-Rubin N. Viral infection in the renal transplant patient. Proc Eur DialysisTransplant Assoc 1983; 19: 513-26.

54. Alonso EM, Fox AS, Franklin WA, Whitington PF. Postnecrotic cirrhosis following varicella hepatitis in a liver transplant patient. Transplantation 1990; 49: 650-3.

55. Patti ME, Selvaggi KJ, Kroboth FJ. Varicella hepatitis in the immunocompromised adult: a case report and review of the literature [see comments]. Am J Med 1990; 88: 77-80.

56. Roque-Afonso AM, Bralet MP, Ichai P, Desbois D, Vaghefi P, Castaign D, et al. Chickenpox-associated fulminant hepatitis that led to liver transplantation in a 63-year-old woman. Liver Transplant 2008; 14: 1309-12.

57. Williams WW. CDC guidelines for the prevention and control of nosocomial infections. Guideline for infection control in hospital personnel. American J Infect Control 1984; 12: 34-63.

58. Alford CA. Acyclovir treatment of herpes simplex virus infections in immunocompromised humans. An overview. Am J Med 1982; 73 (1A): 225-8.

59. Shulman ST. Acyclovir treatment of disseminated varicella in childhood malignant neoplasms. Am J Dis Children 1985; 139: 137-40.

60. Pruksananonda P, Hall C, Insel R, McIntyre K, Pellet PE, Long CE, et al. Primary human herpesvirus 6 infection in young children. N Engl J Med 1992; 326: 1445-50.

61. Hall C, Long C, Schnabel K, Caserta MT, McIntyre KM, Costanzo MA, et al. Human herpesvirus-6 infection in children. A prospective study of complications and reactivation. N Engl J Med 1994; 33: 432-8.

62. Tajiri H, Tanaka-Taya K, Ozaki Y, Okada S, Mushiake S, Yamanishi K. Chronic hepatitis in an infant, in association with human herpesvirus-6 infection. J Pediat 1997; 131: 473-5.
63. Schmitt K, Deutsch J, Tulzer G, Meindi R, Aberle S. Autoimmune hepatitis and adrenal insufficiency in an infant with human herpesvirus-6 infection. Lancet 1996; 348 (9032): 966.

64. Lunel F, Robert C, Munier P, Cadranel JF, Fretz C, Perrin $\mathrm{M}$, et al. Hepatitis virus infections in heart transplant recipients. Biomed Pharm 1995; 49: 125-9.

65. Harma M, Hockerstedt K, Lautenschlager I. Human herpesvirus- 6 and acute liver failure. Transplantation 2003; 76: 536-9.

66. Sobue R, Miyazaki H, Okamoto M, Hirano M, Yoshikawa T, Suga S, Asano Y. Fulminant hepatitis in primary human herpesvirus-6 infection [letter]. N Engl J Med 1991; 324: 1290.

67. Abdel Massih RC, Razonable RR. Human herpesvirus 6 infections after liver transplantation. W J Gastroenterol 2009; 15: 2561-9.

68. Reymen D, Naesens L, Balzarini J, Holy A, Dvorakova $\mathrm{H}$, De Clercq E. Antiviral activity of selected acyclic nucleoside analogues against human herpesvirus 6 . Antiviral Res 1995; 28: 343-57.

69. Hashida T, Komura E, Yoshida M, Otsuka T, Hibi S, Imashuku S, et al. Hepatitis in association with human herpesvirus-7 infection. Pediatrics 1995; 96 (4 Pt 1): 783-5.

70. Cossart Y, Feild A, Cant B, Widdows D. Parvovirus-like particles in human sera. Lancet 1975; 1 (Jan 11): 72-3.

71. Tsuda H. Liver dysfunction caused by parvovirus B19 [letter]. Am J Gastroenterol 1993; 88 (1993 Sep): 1463.

72. Yoto Y, Kudoh T, Asanuma H, Numazaki K, Tsutsumi Y, Nakata S, Chiba S. Transient disturbance of consciousness and hepatic dysfunction associated with human parvovirus B19 infection. Lancet 1994; 344 (27 August): 624-5.

73. Yoto Y, Kudoh T, Haseyama K, Suzuki N, Chiba S. Human parvovirus B19 infection associated with acute hepatitis. Lancet 1996; 347 (30 March): 868-9.

74. Drago F, Semino M, Rampini P, Rebora A. Parvovirus B19 infection associated with acute hepatitis and a purpuric exanthem. Br J Dermatol 1999; 141: 160-1.

75. Karetnyi Y, Beck P, Markin R, Langnas A, Naides S. Human parvovirus B19 infection in acute fulminant liver failure. Arch Virol 1999; 144: 1713-24.

76. Langnas A, Markin R, Cattral M, Naides S. Parvovirus B19 as a possible causative agent of fulminant liver failure and associated aplastic anemia. Hepatology 1995; 22: 1661-5.

77. Sokal E, Melchior M, Cornu C, Vandenbroucke AT, Buts JP, Cohen BJ, Burtonboy G. Acute parvovirus B19 infection associated with fulminant hepatitis of favourable prognosis in young children. Lancet 1998; 352: 1739-41. 
78. Brown K. Parvoviruses. fifth ed. Vol. 2 Philadelphia: Churchill Livingstone; 2000. (Mandell G, Bennett J, Dolin R, eds. Principles and Practice of Infectious Diseases).

79. Pardi D, Romero Y, Mertz L, Douglas D. Hepatitisassociated aplastic anemia and acute parvovirus B19 infection: A report of two cases and a review of the literature. Am J Gastroenterol 1998; 93: 468-70.

80. Zahradnik J, Spencer M, Porter D. Adenovirus infection in the immunocompromised patient. Am J Med 1980; 68: 725-32.
81. Rothenberg M, Cheung R, Ahmed A. Adenovirus-induced acute liver failure. Digest Dis Sci 2009; 54: 218-21.

82. Carmichael GJ, Zahradnik J, Moyer G, Porter D. Adenovirus hepatitis in an immunosuppressed adult patient. Am J Clin Pathol 1979; 71: 352-5.

83. Neofytos D, Ojha A, Mookerjee B, Wagner J, Filicko J, Ferber A, Dessain S, et al. Treatment of adenovirus disease in stem cell transplant recipients with cidofovir. Biology of Blood \& Marrow Transplantation 2007; 13: 74-81. 